This item was submitted to Loughborough's Research Repository by the author.

Items in Figshare are protected by copyright, with all rights reserved, unless otherwise indicated.

\title{
European transport sector intervention for smart city
}

PLEASE CITE THE PUBLISHED VERSION

https://doi.org/10.1109/PESA.2017.8277778

PUBLISHER

IEEE

VERSION

AM (Accepted Manuscript)

LICENCE

CC BY-NC-ND 4.0

REPOSITORY RECORD

Chang, Anna S.F., and Roy S. Kalawsky. 2019. "European Transport Sector Intervention for Smart City". figshare. https://hdl.handle.net/2134/27617. 


\title{
European Transport Sector Interventions for Smart City
}

\author{
Anna S. F. Chang ${ }^{1} \quad$ Roy S. Kalawsky² \\ 1,2, Wolfson School of Mechanical, Electrical \& Manufacturing Engineering \\ Loughborough University, Leicestershire, U.K. \\ ${ }^{1}$ E-mail: a.s.f.chang@lboro.ac.uk 22E-mail: r.s.kalawsky@lboro.ac.uk
}

\begin{abstract}
Digitalization, urbanization, and globalization are changing our world. They are significant drivers enabling cities to grow. We are now moving to a new era of smart cities, yet we know so little about the so-called smart city. In practice, we often hear cities label themselves as 'smart' as they utilize some type of information communication technology (ICT) solutions. By 2050, the population is forecast to be just under 10 billion people, with $80 \%$ of that population expected to be urbanized. Whilst there is wide agreement on exploiting technologies to improve citizen's quality of life, there are other challenges in association with urban growth, such as greenhouse gas emissions, pollution from transport, shortage of energy resources, and inadequate and deteriorating energy infrastructure. The recent announcement of no diesel car ban in cities is a way forward to address environmental challenges inherent in rapid growth. This paper presents the government's initiatives in Europe in supporting the evolution for future transport system.
\end{abstract}

Keywords - smart city, transport infrastructure, European government intervention, London cab, green taxi

\section{INTRODUCTION}

For the first time in history, more people than ever before will live in urban areas. Urban population is expected to double by 2030. Experts anticipate that 730 million people are projected to live in cities by this date. 730 million people represent 8.7 percent of the population globally. [1].

Transport is a key component of the economy. Efficient transport is a precondition for maintaining free movement of passengers and transport of goods [2]. According to the European Environment Agency (EEA) statistics, transport (including international aviation) contributes to a quarter of total greenhouse gas emissions of 4,412 million tons of $\mathrm{CO}_{2}$-equivalent in 2015 [3]. With problematic traffic congestion in most big cities and extreme weather caused by climate change, there is a call for radical reform in the development and deployment of new intelligent transportation and energy solutions in cities.

The European Commission in their 2011 Transport white paper [2] requires the reduction of 'conventionally fueled' cars in urban transportation by half by 2030; the goal is a total phase-out of conventionally fueled cars in cities by 2050; The
European Commission urges for a collective action plan at the international level, as infrastructure takes many years to plan, build and equip. The choices made today will determine transport in 2050. With the popularity of smart city projects around the world, every city must work harder than ever before to reach this goal together; there are now just under a 1000 indicators [4] from different smart city assessment frameworks across different sectors to track sustainable city performance and compare global performers. These indicators can be used to measure progress and learn from successes and challenges to reach the goal of a total phase-out of conventionally fueled cars in cities by 2050 .

\section{SMART CITY CONCEPT}

\section{Smart City Definition}

There are multiple definitions of smart cities. Literature reviews [5] revealed a multitude of terms relating to upgrading of urban infrastructure and services used by policy makers, planners, developers and in academic literatures. Twelve distinct city categories were identified in academic literatures between the period 1996 - 2013, these were: 'eco city', 'sustainable city', 'smart city', 'low carbon city', 'knowledge city', 'intelligent city', 'digital city', 'ubiquitous city', 'resilient city', 'green city', 'information city', and 'liveable city'. The top three terms which appeared most in the Scopus database are in the order of 'sustainable city', 'smart city', and 'digital city' in that period (1996 - 2013).

The British Standards Institute [6], defines "smart cities" as a term denoting the effective integration of physical, digital and human systems in the built environment to deliver a sustainable, prosperous and inclusive future for its citizens.

No agreed definitions has led to urban policy makers interpreting their own judgement on how to make their cities 'smart'. Depending on who is proposing it, each group of stakeholders (government, academia, business, citizen) tends to focus on a special area of interest [7]. Current city projects are not integrated because they belong to a specific sector where integration is not a consideration.

For the purpose of this paper a smart city is an interconnected complex system that uses 
information communication technologies (ICT) to interact with each of its core system, to solve shared urban problems, supporting long term sustainability and empower greater resilience to adapt and transform to extreme event.

\section{Intelligent Transport System}

Intelligent Transport Systems, commonly known as ITS has a big role to play in making the transport system more user friendly, more efficient and safer within the SOS of a smart city. The image of the transport system is sometimes stereotyped by our daily experience, limiting to drivers and physical support staff and the public transport we get on each day. But it actually covers aviation, maritime, ports, inland waterways, logistics, cycling, logistics as well as road, rail and urban transport.

Technology focused definitions:

Intelligent Transport Systems: a combination of Information Technology and telecommunications, allowing the provision of on-line information in all areas of public and private administration [8].

It's called Intelligent Transport Systems (ITS), a catch-all phrase for applying many different technologies to our transport networks, the goal being integrated infrastructure that communicates with vehicles and systems [9].

Broad definition: To maintain and enhance the Agency's capability to deliver intelligent transport systems solutions to better inform travellers, meet network operational and traffic management needs and improve the economic, environmental and safety performance of the technology asset [10].

This study's working definition: ITS uses ICT to maximise journey efficiency by providing timeless data to allow users to travel more safely by improving traffic flow and optimizing existing infrastructure.

\section{Smart City as a Complex System}

An essential element of smart cities is the use of ICT to connect with all embedded sensors (for eample, transport and traffic management (surveillance cameras to monitor real-time traffic volume and road blocks with the aim to provide relief to road congestion, safety and accurate prediction), security $\&$ safety (intrusion alarms, fire, smoke detectors), heath care (heath monitoring), water (flood indicators), waste (read, collect, and transmit trash volume data to optimize waste collection strategies), energy (smart metering to prevent blackouts and brownouts), environment (data on air and noise pollution to improve standard of living) and networks. The digital infrastructure provides the glue to enable the city to operate efficiently in an optimal way. The goal of implementing new technologies into a city to make it 'smart' is to lead to 'increasing citizen satisfaction' and 'protection'. [11][7][12][13]. Intelligent cities make conscious efforts to use information technology to transform life and work [14]. The label "intelligent" implies the ability to support learning, technological development, and innovation in cities.

This suggests that by investing in smart city technology there is much potential to achieve a broad range of goals for the cities. IBM [14] indicates that 'intelligence' refers to the ability to use the information collected through ICT to understand and predict patterns of human behavior and likely outcomes. This understanding can be applied to make informed decisions to support smart growth.

According to the systems engineering book of knowledge's definition, a 'system of system' (SoS) brings together a set of systems for a task that none of the systems can accomplish on its own. Smarter cities transform their systems and their SoS. By optimizing how resources are use, smart cities can boost innovation, which in turn increases competitiveness and economic growth [15].

\section{Smart City of just a City?}

Recently scholars have started criticizing the use of the smart city concept and doubt its effectiveness [12][16][17][18]. It is used for branding [19] and marketing [20]. When an area is promoted as 'smart', the property prices in that area goes up, benefiting only the wealthy [21]. Scholars have raised critical questions on smart city projects. For example, who stands to gain and lose in the race towards such an urban future? [12] Smart urbanism needs to start with the city itself and attends to its social problems, rather than just look at smart technology for answers [22]. Learning from these perspectives, when designing a transport system to meet new legislations, the way to go about should be to focus on the benefits of the city as the priority and promote private car owners to accept connecting transportations to the city. The provision for comfortable and efficient connecting services and with easy to access car parks is essential supporting infrastructure services.

\section{TRANSPORT NEEDS OF FUTURE CITIES}

The benefits of an efficient transport infrastructure not only bring in economic benefits, but will also reduce trade and production costs, increase the value of land and create job opportunities directly to related industries [23].

Intelligent transportation systems in the future require improvements not only in vehicle 
technology, but also the design and set-up of integrated networks linking cars and trucks with roadway infrastructure [24]. Many of these technologies and intelligent transport are still at the theoretical or experimental stage. Such intelligent transportation systems that measure the cost, maintainability, security, robustness, energy footprint, and pollution of a city would be of great interest to city planners and technologists. Furthermore, the collection and analysis of this data on transportation could save time, reduce costs and reduce investment risk. A computational model that allows new types of technologies to be introduced to the transportation system of a city, would therefore be very novel and useful.

\section{UK Urban Traffic Environment}

Efficient transport allows freedom movement of passengers and transport of goods. Smart mobility and transport are approaches which reduce congestion and foster faster, greener and cheaper transportation options [25].

The smooth operation of a transportation system can directly determine the level of economic activity and output of a given city. Consequently, it has the potential to affect both the quality of life for citizens and the economic output of a city [15]. Traditionally, city authorities and planners expand infrastructures by building more roads, tunnels and bridges. Due to financial implications, land constraints, and legacy infrastructures, a radical reform of infrastructure system is called for.

Traffic congestion can have major economic impact. Take for example the UK Report, issued on 20 February 2017, from INRIX claimed that traffic congestion cost UK motorists more than $£ 30$ billion in 2016 [26]

INRIX Global Traffic Scorecard, analyzed the impact of traffic congestion in 1,064 cities across 38 countries worldwide - the largest ever study of its kind, revealed the following facts:

- The UK ranked as the fourth most congested developed country in the world and the third most congested in Europe with drivers spending an average of 32 hours a year in congestion during peak hours. London was the UK's most congested city [26]

- 87 cities and large urban areas were analysed across the UK, and the direct and indirect costs of congestion for all drivers totalled $£ 30.8$ billion in 2016 , an average of $£ 968$ per driver.
The UK is seeking smart transportation solutions. The extensive Intelligent Mobility UK and Travellers Needs Report [27] found that UK travellers are ready for change due to current frustration in travel experiences. $75 \%$ of all journeys made in the UK are subject to negative experiences, $57 \%$ would not mind sharing their data for services, $32 \%$ would share their possessions with others and $39 \%$ would use driverless cars today (Fig 2).

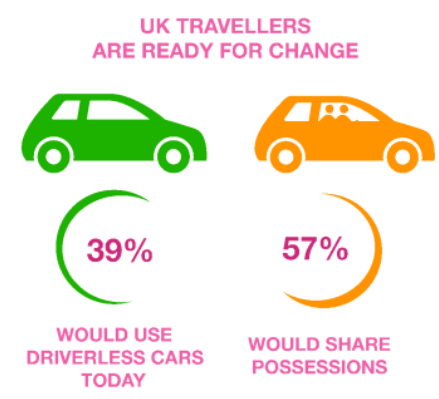

Fig 2: UK Travellers are ready for change (adapted from Transport Systems Catapult)

\section{SMARTER ENERGY UTILIZATION}

During the past years, transport energy consumption has declined less than in other sectors, and therefore its share has continued to increase; it reached $33 \%$ in 2009 for the EU-27 (including international aviation but not international maritime) [28] .

Most cities are supplied with electricity from largescale power plants, supplied over a distance as short as possible to reduce transmission losses. Similarly, trucks, cars, and aircraft require fuel with high energy content. Switching to electric vehicles will likely intensify the need for concentrated sources of energy and requires a complex fuel distribution network [29]. Figure 3 shows attempts to show the causal loop diagram of the transport metaphor.

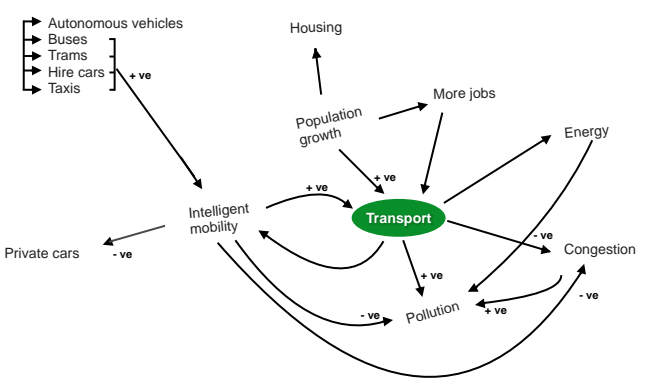

Fig3: Causal loop diagram of the transport metaphor

With all these promising action plans of switching to green mobility by 2030 by some German federal states and state pressure for adoption of clean and environmentally sound technologies for transport, the big question is where the power will come from to accommodate the big boom. 
On a global forecast, the IEA agency estimates that there will be 140 million electric cars by 2030 if countries meet the Paris climate deal's goal of avoiding dangerous temperature rises [38].

One Think Tank, a popular BBC quiz show [30] warned that as few as six electric cars in one neighbourhood could risk a 'brownout' - due to an unexpected drop in voltage. With legacy infrastructure in most urban cities, installation of new infrastructure and upgrading the capacity will be a challenge. At the same time, managing the peak demand when everyone charges their electric vehicles when they go to work and when they return home is a further challenge. This will put immense demand pressure on the grid. These concerns may seem far off, but if we don't plan ahead for the predicted extra capacity on energy demand on future transportation, we will be heading to a phenomenon of power crisis.

Providing secure and sustainable energy for their citizens is a key challenge for cities. Cities face interconnected challenges. These challenges and threats to sustainability come from all angles, they are also interrelated. Deployment of new intelligent transportation systems and distributed energy solutions only 'solve one' of the system of systems. Stakeholders must integrate as 'all' to serve the real purpose behind the smart city concept - to enhance quality of services to its citizen.

\section{EUROPEAN GOVERNMENT INTERVENTIONS}

\section{United Nation - The 2030 Agenda}

The 2030 Agenda for Sustainable Development is a plan of actions where all countries and all stakeholders come together to implement the transform our world action plans. Goal 9: 'To build resilient infrastructure to promote inclusive and sustainable industrialization and foster innovation.'

The target is by 2030, infrastructure should be upgraded and to retrofit industries to make them sustainable, with increased resource - use efficiency and greater adoption of clean and environmentally sound technologies and industrial processes, with all countries taking action in accordance with their respective capabilities.

\section{ITU and UNECE}

ITU and UNECE launched 'United for Smart Sustainable Cities' (U4SSC) in response to the Sustainable Development Goal 11: 'Make cities and human settlements inclusive, safe, resilient and sustainable.'

U4SSC advocates for public policy to encourage the use of ICTs to facilitate and ease the transition to smart sustainable cities. U4SSC serves as the global platform for discussions on smart sustainable cities. Business: Cities must balance complex regulatory requirements with the need to minimize unnecessary administrative burdens.

\section{European Union}

On 6th July 2017, the French Government announced that it will ban sales of petrol and diesel cars by 2035 . Volvo, a leading car manufacturer in the UK, also announced in the same week that it would only make fully electric or hybrid cars from 2019 onwards. The Netherlands has also proposed the ban for diesel and petrol cars by 2025, and some federal states in Germany are keen to adopt on a 2030 total phase-out [30].

\section{UK Transport Sector Intervention}

The potential lost opportunity (GDP) cost for the transport industry is $£ 50$ billion per annum if interventions are not put in place [56]. Suggestions for interventions include: Building new intelligent mobility hubs to align academia with industry to create and deliver higher level and fast track apprenticeship; science school to support high value digital skills for future transport needs; create new academic qualifications and accreditations; Further, the UK government has demonstrated its commitment to secure significant funds in the emerging $£ 900$ billion intelligent mobility market through a range of recent investments. These include the setting up of the Transport Systems Catapult (TSC); the Centre for Connected and Autonomous Vehicles (CCAV) in July 2015; $£ 200$ million fiveyear Intelligent Mobility Programme ( $£ 100$ million from government and $£ 100$ million in matched funding from industry);

Stricter New Emission Test

Starting from $1^{\text {st }}$ September 2017, all new diesel and petrol cars must pass stricter test before they are allowed on British roads [31]. Under the new test, vehicles will have to go through a 90-minute real world driving test instead of the conventional rolling road test inside the lab. The British government is leading the way to reduce pollutant cars off the road. Nitrogen oxide emissions requirements will be even stricter from $1^{\text {st }}$ September 2020 for all new car models. The new test is also designed to prevent car manufacturers cheating on the emissions test. The case with Volkswagen was openly publicized when it revealed that they manipulated the test results with sensors when the vehicle was running on a rollingroad in the lab.

\section{Government Commits £11million to Green Buses}

Following the Air Quality Plan published in July 2017, 153 cleaner buses will hit the road next year. Six cities in the U.K have been awarded funding under the Government's 'Low Emission Bus 
Scheme' [32]. Later in the year, the Government will publish plans for more grant to support the cleanest buses on British streets. The government's support for low emission buses is one part of a $£ 600$ million package of measures from the Office for Low Emission Vehicles by 2020.

\section{Faraday Battery Institute}

In the October 2017 press release, from the Business Strategy Department, it announced the formation of a consortium - the new £65 million Faraday Battery Institute, bring together by 7 leading UK universities. The goal is to bring UK's status as a global leader in battery research and technology [33]. The funding is through the Engineering and Physical Sciences Research Council (EPSRC). The new research centre is divided into 3 streams - research, innovation and scale-up to bring British technologies to economic successes. A further $£ 246$ million will be made available over the 4 years to support the Faraday Research Challenge to build its strengths to lead the world in electric batteries design, development and manufacturing.

\section{London Black Cabs go Green}

Starting from January 2018, only "zero emissions vehicles" will be allowed into London. No vehicle license will be issued, banning new diesel taxis completely to the capital. Transport for London will offer grants of up to $£ 5,000$ to encourage the upgrade. Currently, there are 24,000 taxis on the streets of Greater London. Transport authorities have put in plans for 300 rapid 50kw chargers by 2020 , with 75 units to be fitted before the end of 2017. This is in additional to the slow chargers. The list price for these purpose-built pure electric vehicles is around $£ 55,000$ with basic range of up to 70 miles per charge. With the assistance of a 1.5 litre petrol range extender, [34] it claims the range can go up to 400 miles.

\section{Diesel and Petrol Vehicle Ban}

In the last few months, there are a number of countries in Europe, which have imposed legislations on the future of fossil fuel vehicles. UK and France will ban gasoline and diesel cars in cities starting 2035, Scotland will go one step further with a 2032 target. Some cities in Germany will start the ban on 2030. In Asia, India will start the ban on 2030. China has not fixed a time line but it is about 2025. Therefore, the impact of EV on the global market is much fast than we expected.

\section{CONCLUSION}

Developing "Smart Cities" will be a high priority for many stakeholders, including government bodies, research institutions, environmentalists, and the private corporations. Cities are increasingly investing in green transportation, for example, recently, the British government requires cars to pass stricter emissions tests before they are allowed on the road. A city is a complex system, including not only the transportation system, but also other sub-systems that can be improved to be made greener and more efficient; the challenge is how to optimize city resources to achieve competitiveness and economic growth. Sensors, advances in connected vehicles, maturing powertrain technologies, power distribution, safety, monitoring and control, battery cycling are key issues to effective transport system. Starting from January 2018, no vehicle license will be issued to new diesel cabs, only 'zero emissions vehicles' will be allowed in London. This new ban on conventional vehicles will mean cities must invest in intelligent transportation to save money and meet new requirements - an additional benefit of intelligent transportation will be a reduction in emissions. This rapid change is an opportunity to develop cities that impact our health and quality of life with better air quality, and a novel way to commute. This smart growth not only improves citizens' health, but can also slow climate change. The ultimate goal is, of course, a better life and a cleaner earth. New legislation, government programmes and interventions have triggered the rapid research and development - this research and development marks the beginning of a new era of transportation. There is no single answer or single technology to road transport decarbonisation strategy. To meet the 2040 government target to end the sales of new diesel and patrol cars, further research is required to examine the barriers to the development of the electric vehicle market. New technology trends such as driverless cars will also play a role in how smart cities develop. The next decade is vital to set the infrastructure 'at scale' and 'commercialise' low carbon footprint technologies. This paper has highlighted government initiatives within Europe in support of the evolution for future transport system. The whole question of how to deal with legacy transport infrastructure and current vehicles remains, but will need to be solved? This is one of the most important critical success factors that needs to be delivered in order to create sustainable smart cities. A key challenge will be how well the various stakeholders deliver such transformations in a way that are economical and efficient through a series of transitionary steps.

\section{REFERENCES}

\footnotetext{
"The aging of the population demands a fundamental shift in planning in order to minimize the economic, social and health challenges that will otherwise overwhelm communities. 6 Guiding Policies for Planners:
} 
APA AGING IN COMMUNITY POLICY GUIDE THE AGING OF AMERICA By the Numbers."

[2] European Commission, Roadmap to a Single European Transport Area-Towards a competitive and resource efficient transport system. 2011.

[3] J. G. J. Olivier, M. Muntean, and J. A. H. W. Peters, "Trends in Global CO2 Emissions 2016 Report," PBL Netherlands Environ. Assess. Agency Eur. Comm. Jt. Res. Cent., pp. 6-86, 2016.

[4] H. Ahvenniemi, A. Huovila, I. Pinto-Seppä, and M. Airaksinen, "What are the differences between sustainable and smart cities?, Cities, 2017.

[5] M. De Jong, S. Joss, D. Schraven, C. Zhan, and M. Weijnen, "Sustainable-smart-resilient-low carbon-eco-knowledge cities; Making sense of a multitude of concepts promoting sustainable urbanization," J. Clean. Prod., 2015.

[6] BSI, "PAS 180:2014 Smart cities - Vocabulary," Pas, p. 38, 2014.

[7] L. Bertolini, U. Van Amsterdam, V. Bettini, R. Leonardi, and R. Fistola, "EDITOR IN-CHIEF," TeMA J. L. Use Mobil. Environ. CITIES, ENERGY Clim. Chang. TeMA J. L. Use Mobil. Environ. TeMA J. L. Use Mobil. Environ., vol. 1, no. $1,2015$.

[8] A. Gaur, B. Scotney, G. Parr, and S. McClean, "Smart city architecture and its applications based on IoT," in Procedia Computer Science, 2015.

[9] "The smart future of transport management and operation," CGI, ntelligent Transport System. [Online]. Available: https://www.cgigroup.co.uk/transport-and-logistics/intelligenttransport-systems\%0D. [Accessed: 06-Nov2017].

[10] D. Cowell, "Intelligent Transport Systems," Highways England. [Online]. Available: http://www.highways.gov.uk/knowledge/innova tion-programme/2009-11-knowledge-

programme/04-intelligent-transportsystems/\%0D. [Accessed: 06-Nov-2017].

[11] G. Hollands, "Will the real smart city please stand up?," City, vol. 12, no. 3, pp. 303-320, 2008.

[12] R. G. Hollands, "Critical interventions into the corporate smart city," Cambridge J. Reg. Econ. Soc., vol. 8, no. 1, pp. 61-77, 2015.

[13] U. Rosati and S. Conti, "ScienceDirect 2nd International Symposium 'NEW METROPOLITAN PERSPECTIVES' -Strategic planning, spatial planning, economic programs and decision support tools, through the implementation of Horizon/Europe2020 What is a smart city project? An urban model or a corporate business plan?," Procedia -Social Behav. Sci. Reggio Calabr., vol. 223, pp. 968973, 2016.

[14] N. Komninos, M. Pallot, and H. Schaffers, "Special Issue on Smart Cities and the Future Internet in Europe," J. Knowl. Econ., 2013.

[15] S. Dirks and M. Keeling, "A vision of smarter cities: how cities can lead way into a prosperous and sustinable future," IBM Glob. Bus. Serv., pp.
$1-18,2009$.

[16] M. de Lange and M. de Waal, "Owning the city: New media and citizen engagement in urban design," A Gt. Cities Initiat. Univ. Illinois Chicago, 2013.

[17] R. Kitchin, "Making sense of smart cities: addressing present shortcoings," Cambridge J. Reg. Econ. Soc., vol. 8, no. 1, pp. 131-136, 2015.

[18] P. Walravens, Nils; Breuer, Jonas; Ballon, "Open Data as a Catalyst for the Smart City as a Local Innocation Platform," Commun. Strateg., vol. 96, no. 4th quarter, p. 15, 2014.

[19] A. Vanolo, "Smartmentality: The Smart City as Disciplinary Strategy," Urban Stud., vol. Early View, no. April, pp. 1-16, 2013.

[20] T. Shelton, M. Zook, and A. Wiig, "The 'actually existing smart city,"” Cambridge J. Reg. Econ. Soc., vol. 8, pp. 13-25, 2015.

[21] P. Neirotti, A. De Marco, A. C. Cagliano, G. Mangano, and F. Scorrano, "Current trends in smart city initiatives: Some stylised facts," Cities, 2014.

[22] C. A. Kennedy, N. Ibrahim, and D. Hoornweg, "Low-carbon infrastructure strategies for cities," Nat. Clim. Chang., vol. 4, no. 5, pp. 343-346, 2014.

[23] C. Gottbehüt, "Smart connected business Internet of things Smart transport infrastructure," 2016.

[24] TALAL AL-KHATIB, "Intelligent Transportation Systems: The future of travel?," How stuff works. [Online]. Available: http://science.howstuffworks.com/environmenta 1/energy/intelligent-transportation-systems.htm. [Accessed: 22-Aug-2017].

[25] K. Campbell, D. Carriero, A. Dzikus, A. Reynolds, R. Robinson, and T. Stonor, "Issues Paper on Smart Cities and Infrastructure," 2015.

[26] M. Simmons, "Traffic congestion to cost UK economy," INIX, 2017. [Online]. Available: http://inrix.com/press-releases/traffic-

congestion-cost-uk-motorists-more-than-30billion-in-2016/. [Accessed: 25-Jul-2017].

[27] J. Chan-Pensley, "Traveller Needs \&amp; amp; UK Capability Study," Tranport Syst. Catapult.

[28] "Transport," European Environment Agency, $2017 . \quad$ [Online]. Available: https://www.eea.europa.eu/themes/transport.

[Accessed: 15-Aug-2017].

[29] The World Bank, "Cities and Climate Change: An Urgent Agenda - Part III: Cities' Contribution to Climate Change," World Bank, vol. 10, pp. 1432, 2010.

[30] H. Briggs, "Global CO2 emissions 'stalled' in 2015," BBC News, 2015.

[31] P. Maynard, "Tough new 'real world' test comes into force for diesel cars to clean up our air," Department of Transport, 2017. [Online]. Available:

https://www.gov.uk/government/news/toughnew-real-world-test-comes-into-force-fordiesel-cars-to-clean-up-our-air. [Accessed: 17Oct-2017].

[32] P. Maynard, "Cleaner journeys as government commits £11 million to greener buses," Department of Transport, 2017. .

[33] G. Clark, "Business Secretary announces founding partners of $£ 65$ million battery 
technology research institute," Department for Business, Energy \& Industrial Strategy, 2017.

[Online]. Available: Business Secretary announces founding partners of $£ 65$ million battery technology research institute. [Accessed: 17-Oct-2017].

[34] K. Bradshaw, "Black cabs go green: Electric taxis on the way," Sky News, 2017. [Online]. Available: https://www.i-scoop.eu/digitaltransformation/transportation-logistics-supplychain-

management/?utm_campaign=shareaholic\&utm _medium=email_this\&utm_source=email.

[Accessed: 27-Sep-2017]. 